\title{
PENGARUH KINERJA MESIN DIESEL YANMAR L-40-E-DT TERHADAP EMISI GAS BUANG
}

\author{
Surianto Buyung \\ Dosen Jurusan Mesin, Politeknik Katolik Saint Paul Sorong \\ e-mail : jevan@yahoo.co.id
}

\begin{abstract}
ABSTRAK
Penelitian ini mempelajari Pengaruh Kinerja Mesin terhadap Emisi Gas buang sebagai campuran bahan bakar solar terhadap prestasi mesin Diesel. Zat-zat yang merugikan dalam gas buang adalah karbon hydrogen, nitrogen monoksida dan karbon monoksida. Pengujian dilakukan dengan menggunakan alat test emisi gas buang pada pembebanan 750, 1000 dan 250 pada putaran kostan 3000 rpm.

Dari hasil pengujian menunjukkan Semakin besar pembebanan semakin menaikkan daya mesin maka, kadar oksigennya menurun. Semakin besar pembebanan pemakaian bahan bakar semakin naik, kadar oksigen menurun, kadar carbon dioksida naik, kadar oksida nitrogen juga mengalami penurunan, kadar karbon monoksida naik.

Perubahan Efisiensi thermal sangat mempengaruhi penurunan dan kenaikan unsur-unsur kimia yang terkandung didalam gas buang, dimana kadar oksigen, karbon dioksida naik, kadar oksida nitrogen turun.

Karbonmonksida yang dihasilkan oleh gas buang Mesin Diesel Yanmar L 40 sebesar 0,1\% lebih kecil dari 0,3\% masih dalam kondisi yang diizinkan, layak untuk dioperasikan
\end{abstract}

Kata kunci: Emisi gas buang, Prestasi mesin

\begin{abstract}
This research studies engine performance influence to exhaust emission of gas as diesel fuel fuel mixture to diesel engine performance. Matters harming in exhaust gas is carbon hydrogen, nitrogen monoxide and monoxide carbon. Assaying is done by using exhaust emission of gas test device at encumbering 750, 1000 and 250 at revolution kostan 3000 rpm.

From result of assaying shows ever greater of encumbering increasingly boosts up engine energy power hence, the oxygen grade declines. ever greater of usage encumbering of fuel increasingly rising, oxygen grade declines, grade dioxide carbon rising, nitrogen oxide grade also experiences derivation, rising monoxide carbon grade.

Transformation of efficiency thermal hardly influences derivation and increase of consisting in chemistry elements in exhaust gas, where oxygen grade, rising carbon dioxide, nitrogen oxide grade downwards. Monoxide carbon yielded by diesel engine yanmar L-40 exhaust gas equal to 0,1\% smaller than 0,3\% still in condition permitted, competent to be operated
\end{abstract}

Keyword: Exhaust emission of gas, Engine performance

\section{PENDAHULUAN}

Dalam perkembangan teknologi permesinan, pada masa sekarang ini khususnya mesin diesel, dapat dilihat berbagai macam manfaat serta kegunaannnya bagi masyarakat. Meskipun peranannya banyak membantu, secara tidak sadar gas buang yang dihasilkan oleh mesin diesel banyak memberikan dampak negatif bagi lingkungan dan kesehatan manusia, dimana hasil pembakaran tersebut berupa gas buang seperti Nox dan $\mathrm{CO} 2$.

Proses pembakaran atau penguapan bahan bakar tersebut akan menghasilkan gas buang (emisi). Atmosfer yang bisa disebut "udara" terdiri dari gas utama, yaitu Oksigen (O2) sebanyak kurang lebih $21 \%$ volume dan Nitrogen (N2) sebanyak kira-kira 78\% dari bagian atmosfer. Sisa 1\% lainnya dari berbagai gas, yaitu Argon (Ar) sebanyak 0,94\%, sisanya 0,06\% terdiri dari CO2, CO, HC, NOx, SOx, dan lain-lain.

Mesin Diesel merek Yanmar type L-40 E-DT sudah beroperasi selama 20 tahun dirasa perlu diadakan studi kelayakan tingkat pencemaran gas buangnya. 
Gas buang.

Adapun tujuan dari penelitian ini adalah mengetahui Pengaruh Kinerja Mesin terhadap Emisi

Batasan Masalah

Karena kompleksnya permasalahan pada pengujian prestasi mesin Diesel, maka masalah dibatasi yaitu

- Pengujian dilakukan dengan menggunakan Mesin Diesel Yanmar type L-40 E- DT dengan volume langkah adalah 1,54-4 $\mathrm{cm}^{3}$ dan jumlah silinder adalah 1 (satu),

- Pembahasan difokuskan pada daya mesin, pemakain bahan bakar dan Efisiensi thermal hubungannya dengan Emisi Gas Buang,

- Pembebanan Mesin 750,1000, dan 1250 gram

- Putaran Mesin bervariasi 1650, 1700, 1750, 1800 dan 1850 rpm pada setiap pembebanan.

Bagian-bagian gas buang yang sangat mengganggu kesehatan adalah :

- Karbonmonoksida (CO)

Banyaknya $\mathrm{CO}$ dari gas buang itu tergantung dari perbandingan bahan bakar dan udara .Hanya pada pembakaran yang sempurna dari bahan bakarnya maka nilai $\mathrm{CO}$-nya dapat nihil. Hal ini dapat dicapai pada perbandingan secara teoritis 14,8:1. Perbandingan sebesar ini selama mesin berjalan jarang dapat dipertahankan karena kualitas campuran selalu berubah dengan frekwensi putar dan pembebanan mesin

Karbonmonoksida yang banyaknya $0,3 \%$ sudah merupakan racun yang sangat berbahaya untuk udara yang diisap oleh manusia. Jumlah sebanyak $0,3 \%$ selama setengah jam diisap adalah mematikan.

- Karbon hidrogen

Didalam gas buang terdapat juga zat karbon hidrogen yang belum terbakar Banyaknya tergantung dari keadaan waktu mesin bekerja.

Pada keadaan hampa dalam silinder dan katup gas tertutup,jumlah karbon hidrogen yang tidak terbakar banyak sekali

Zat-zat yang merugikan dalam gas buang adalah;

- CH (karbon hidrogen ) ini adalah merupakan pengisapan bahan bakar dan bahan bakar yang tidak terbakar

- NO (nitrogen monoksid) Gas ini dibentuk dalam motor khusus pada suhu tinggi. Diudara luar masih menyatu dengan zat asam ,sehingga terjadi nitrogen dioksida (NO2) Dibawah pengaruh sinar matahari akan timbul kabut NO2 yang dapat menimbulkan rasa nyeri pada mata dan selaput lain. Gas ini juga akan merusak tumbuh tumbuhan

- CO ( karbonmonoksida ) Gas ini dalam badan manusia akan menyerang butir-butir darah merah yang bertugas membawa zat asam keseluruh badan manusia. Didalam ruang tertutup prosentase volume $\mathrm{CO}$ $0,3 \%$ sudah mematikan

\section{LANDASAN TEORI}

Prinsip Kerja Motor Diesel

- Langkah masuk (isap)

Katup masuk membuka, torak bergerak dari TMA (titik mati atas) ke TMB (titik mati bawah). Jadi poros engkol memutara (terus) $180^{\circ}$. Tekanan di dalam silinder rendah.

Disebabkan selisih tekanan antara udara luar dan tekanan rendah di dalam silinder, maka udara mengalir ke dalam silinder. Tidak terdapat katup pengatur seperti pada motor bensin. Udara dapat mengalir masuk tidak terbatas. Motor diesel bekerja dengan sisa udara. Pada motor-motor besar dengan muatan penuh kira-kira mencapai jumlah $100 \%$. Pada motor-motor kecil sekitara 40\%.

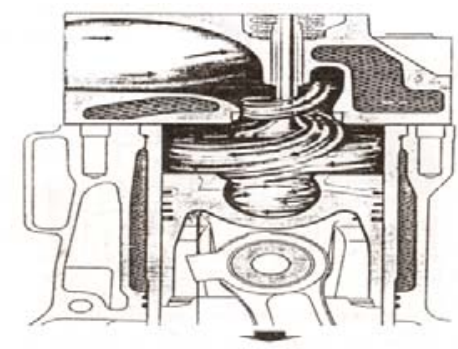

Pusaran Udara selama langkah masuk

Dengan cara demikian sebuah motor diesel juga bekerja dengan penyemprotan bahan bakar maksimal, tanpa asap. Dengan menggunakan kompresor silinder yang bertekanan, menyebabkan lebih banyak udara mengalir dalam silinder-silinder daripada pengisian secara alami. 


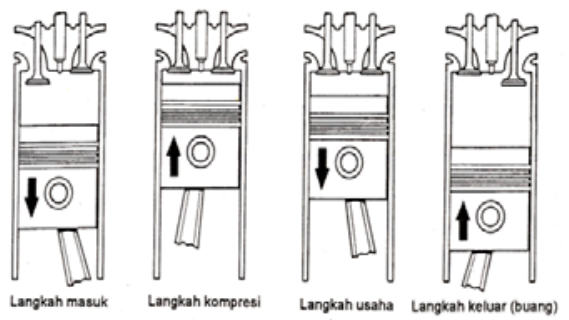

Cara Kerja Motor Disel 4 Langkah

- Langkah kompresi

Selama langkah kompresi katup masuk dan katup keluar tertutup. Torak bergerak dari TMB ke TMA.

Poros engkol berputar terus $180^{\circ}$ lagi. Udara yang ada dalam silinder, dimampatkan kuat di atas torak dan menyebabkan temperature naik.

- Langkah Usaha

Selama langkah usaha, katup masuk dan katup keluar dalam keadaan tertutup. Pada akhir langkah kompresi, pompa penyemprotan bertekanan tinggi itu menyebabkan sejumlah bahan bakar dengan ketentuan sempurna ke dalam udara yang dimampatkan panas oleh sebuah pengabut. Bahan bakar itu terbagi sangat halus dan bercampur dengan udara panas. Karena temperature tinggi dari udara yang dimampatkan, maka bahan baker itu langsung terbakar.

Akibatnya, tekanan naik dan torak bergerak dari TMA ke TMB. Poros engkol terus berputar lagi $180^{\circ}$. Untuk pembakaran bahan baker 1 gram, secara toritis diperlukan 15, 84 gram udara. Secara praktis, untuk pembakaran yang baik campuran bahan bakar-udara yang sempurna memerlukan perbandingan sempurna 20-25 gram udara.

- Langkah keluar (Pembuangan)

Pada akhir langkah keluar katup pembuangan membuka. Torak bergerak dari TMB ke TMA dan mendorong gas-gas pembakaran ke luar melalui katup buang yang terbuk. Jadi, dipandang secara toritis pada motor disel empat tak, katup masuk (isap) dan katup keluar (buang) bersama-sama menutup dan hanya selama $180^{\circ}$ menghasilkan usaha.

Semakin banyak silinder sebuah motor, maka langkah usaha akan semakin banyak setiap $720^{\circ}$ atau membuat dua putaran.
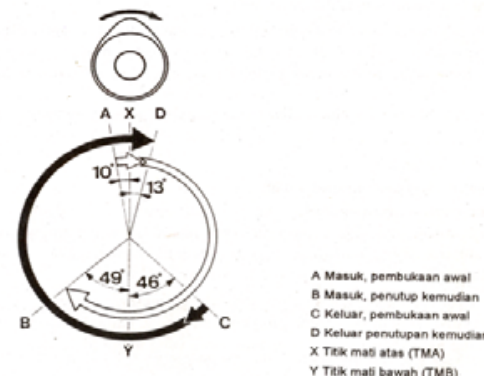

Diagram katup motor Diesel 4 langkah

\section{Proses Pembakaran Pada Motor Diesel}

Proses pembakaran pada motor bakar khususnya mesin diesel terjadi secara periodik. Urutan kejadian berulang secara teratur dan dalam urutan yang sama (cycle). Beberapa kejadian berikut membentuk daur dalam mesin diesel :

1. Mengisi silinder mesin dengan udara.

2. Penekanan isi utama yang menaikkan tekanan dan suhu sehingga bahan bakar yang diinjeksikan ke dalam silinder akan terbakar secara efisien.

3. Pembakaran bahan bakar dan pengembangan gas panas.

4. Mengosongkan silinder dari hasil pembakaran.

Apabila ke empat proses ini diselesaikan, maka daur diulangi kembali.

Bahan bakar di dalam tangki disalurkan ke luar oleh pompa penyalur, lalu melalui saringan pompa penyualur terus ke pompa bahan bakar melalui nozel injeksi. Bahan bakar yang merembes dari nozel 
ditampung oleh pipa laeakage dan kembali kesaluran masuk pompa penyalur, dan selanjutnya ke pompa bahan bakar kembali di mana akan diteruskan ke ruang bahan bakar, sesuai dengan proses tersebut diatas. Pembakaran yang sempurna didalam silinder motor diesel terutama tergantung pada syarat-syarat sebagai berikut :

- Derajat pengabutan bahan bakar.

- Suhu yang tinggi untuk memperoleh pembakaran yang sempurna dari bahan bakar dan udara.

- Kecepatan relative yang tinggi antara partikel bahan bakar dan udara (400 meter/detik).

- Partikel yang baik antara bahan bakar dan udara.

Siklus Thermodinamika Motor Diesel

Dalam usaha menganalisa proses motor bakar umumnya digunakan siklus udara sebagai siklus ideal, dimana siklus udara menggunakan beberapa keadaan yang sama dengan siklus yang sebenarnya, yaitu urutan proses, perbandingan kompresi dan pemilihan temperature dan tekanan.

Siklus toritis untuk penyalaan kompresi 4 langkah dapat dilihat pada gambar 2.5 dengan pemanasan pada tekanan kontstant, dimana udara dikompresikan sampai mencapai temperatur nyala bahan bakar, kemudian bahan bakar diinjeksikan dengan laju penyemprotan sedemikian rupa sehingga dihasilkan proses pembakaran pada tekanan constant, dimana penyalaan bahan bakar diakibatkan oleh suatu kompresi.

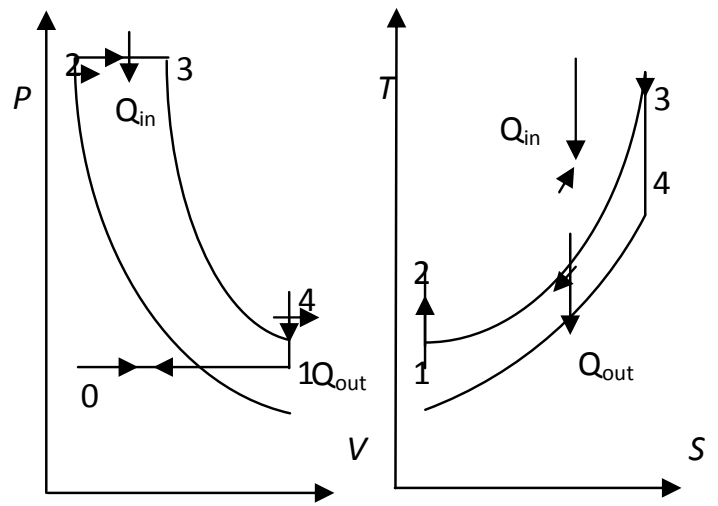

Diagram P-V dan T-S Siklus Diesel

Proses - proses yang terjadi :

- Proses $(0-1)=$ Langkah isap (udara murni) pada tekanan konstan

- Proses $(1-2)=$ Langkah kompresi isentropic

- Proses $(2-3)$ = Proses pembakaran (pemasukan kalor pada volume konstan)

- Proses $(3-4)=$ Pemasukan kalor pada tekanan konstan.

- Proses $(4-5)=$ Langkah ekspansi (kerja) dalam keadaan isentropic

- Proses $(5-1)=$ Proses pembuangan (pengeluaran kalor) pada volume konstan

- Proses $(1-0)=$ Langkah buang pada tekanan konstan.

\section{METODE PENELITIAN}

Alat yang digunakan :

1. Tachometer

Dipakai untuk mengukur besarnya putaran mesin .

2. Stop Watch

Digunakan untuk mengetahui waktu pemakaian bahan bakar

3. Alat Tes Emisi gas buang

Digunakan untuk mengukur zat-zat yang terkandung dalam gas buang.

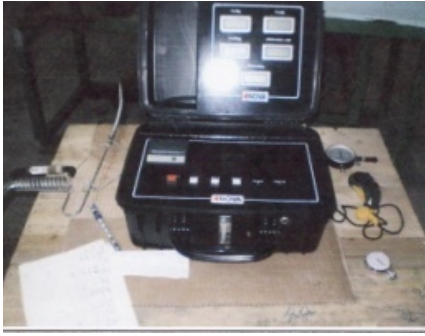

Alat test emisi gas buang 


\section{Prosedur Penelitian}

Pada pengujian ini dilakukan variasi pembebanan yaitu : 750,1000 dan 1250 gram pada putaran mesin konstan 3000 rpm dengan prosedur sebagai berikut :

a. Jalankan mesin

b. Atur pembebanan mesin pada beban 750 gram

c. Ukur putaran mesin dan konstankan pada $3000 \mathrm{rpm}$

d. Ukur waktu pemakaian bahan bakar

e. Ukur beda tekanan orifice

f. Ukur Zat- zat yang terkandung pada gas buang

g. Ulangi point $\mathrm{c}$ hingga point $\mathrm{f}$ pada setiap perubahan pembebanan

h. Matikan Mesin

\section{HASIL DAN PEMBAHASAN}

Pada pembahasan dan analisa pengaruh prestasi mesin terhadap zat- yang terkandung dalam gas buang mesin Diesel type Yanmar L-40C dipokuskan pada; Hubungan antara Daya Mesim dengan Oksigen, Carbon Dioksid, Carbon Monoksid, Hidrro Carbon, dan Oksida Nitrogen.

Hal yang sama juga dilakukan pada, Pemakaian Bahan bakar dan Effisiensi Thermal.

Adapun hasil pengamatan dan perhitungan adalah

- Hasil pengamatan

Hasil pengamatan

\begin{tabular}{|c|c|c|c|c|c|c|c|c|c|}
\hline No & $\begin{array}{l}\text { Beban } \\
\text { (m) kg }\end{array}$ & $\begin{array}{c}\text { Putaran (n) } \\
\text { rpm }\end{array}$ & $\begin{array}{c}\Delta \mathbf{h} \\
(\mathrm{mm})\end{array}$ & $\begin{array}{l}\text { Waktu } \\
\text { (t) } s\end{array}$ & $\begin{array}{r}\mathrm{O}_{2} \\
(\%)\end{array}$ & $\begin{array}{l}\mathrm{Co}_{2} \\
(\%)\end{array}$ & $\begin{array}{c}\text { NoX } \\
(\%)\end{array}$ & $\begin{array}{l}\mathrm{Hc} \\
(\%)\end{array}$ & $\begin{array}{l}\text { CO } \\
(\%) \\
\end{array}$ \\
\hline 1 & \multirow{5}{*}{750} & 1850 & 32 & 173 & 17.6 & 2.5 & 50 & -9 & 0 \\
\hline 2 & & 1800 & 29.5 & 180 & 17.6 & 2.5 & 53 & -9 & 0 \\
\hline 3 & & 1750 & 28 & 190 & 17.7 & 2.4 & 54 & -10 & 0 \\
\hline 4 & & 1700 & 27 & 195 & 17.9 & 2.2 & 56 & -9 & 0 \\
\hline 5 & & 1650 & 26 & 198 & 18 & 2.2 & 58 & -10 & 0 \\
\hline 1 & \multirow{5}{*}{1000} & 1850 & 33 & 164 & 18.4 & 2.6 & 53 & -8 & 0 \\
\hline 2 & & 1800 & 30 & 182 & 18.2 & 2.6 & 58 & -8 & 0 \\
\hline 3 & & 1750 & 29 & 186 & 17.9 & 2.3 & 54 & -9 & 0 \\
\hline 4 & & 1700 & 28 & 190 & 17.3 & 2.7 & 62 & -9 & 0 \\
\hline 5 & & 1650 & 27 & 195 & 17.5 & 2.5 & 66 & -9 & 0 \\
\hline 1 & \multirow{5}{*}{1250} & 1850 & 34 & 148 & 16.9 & 3.7 & 80 & -3 & 0.1 \\
\hline 2 & & 1800 & 33 & 150 & 16.8 & 3.1 & 72 & -3 & 0.1 \\
\hline 3 & & 1750 & 31 & 158 & 16.8 & 3 & 63 & -1 & 0.1 \\
\hline 4 & & 1700 & 30 & 162 & 16.5 & 3.2 & 84 & -4 & 0.1 \\
\hline 5 & & 1650 & 28 & 170 & 16,0 & 2.1 & 79 & -7 & 0.1 \\
\hline
\end{tabular}

- Hasil perhitungan pada beban 750 gr

Hasil Perhitungan pada beban 750 gr

\begin{tabular}{|c|c|c|c|c|c|c|c|c|c|c|c|}
\hline NO & $\begin{array}{c}\text { Putaran } \\
\mathrm{n}(\mathrm{rpm})\end{array}$ & $\begin{array}{c}\text { Daya Ne } \\
(\mathrm{kw})\end{array}$ & $\begin{array}{c}\mathrm{P}_{\mathrm{e}} \\
(\mathrm{kpa})\end{array}$ & $\begin{array}{c}\mathrm{FC} \\
(\mathrm{kg} / \mathrm{jam})\end{array}$ & $\begin{array}{c}\mathrm{Qa} \\
\left(\mathrm{m}^{3} / \mathrm{s}\right)\end{array}$ & $\begin{array}{c}\mathrm{SFC} \\
(\mathrm{kg} / \mathrm{kw} . \mathrm{jam})\end{array}$ & $\begin{array}{c}\mathrm{m}_{\mathrm{a}} \\
(\mathrm{kg} / \mathrm{jam})\end{array}$ & $\begin{array}{c}\mathrm{m}_{\mathrm{at}} \\
(\mathrm{kg} / \mathrm{jam})\end{array}$ & AFR & $\begin{array}{c}\eta \mathrm{v} \\
(\%)\end{array}$ & $\begin{array}{c}\eta \text { th } \\
(\%)\end{array}$ \\
\hline 1 & 1850 & 0.349041026 & 147.0162 & 0.170636 & 0.00084 & 0.48887 & 3.478983 & 9.82905 & 20.38835 & 35.39491 & 16.66044 \\
\hline 2 & 1800 & 0.339607485 & 147.0162 & 0.164 & 0.000807 & 0.48291 & 3.340322 & 9.82905 & 20.36782 & 33.98418 & 16.86606 \\
\hline 3 & 1750 & 0.330173944 & 139.0694 & 0.155368 & 0.000786 & 0.470565 & 3.254291 & 9.82905 & 20.94564 & 33.10891 & 17.30853 \\
\hline 4 & 1700 & 0.320740403 & 135.096 & 0.151385 & 0.000772 & 0.471985 & 3.19565 & 9.82905 & 21.10948 & 32.5123 & 17.25648 \\
\hline 5 & 1650 & 0.311306861 & 131.1226 & 0.149091 & 0.000757 & 0.478919 & 3.135913 & 9.82905 & 21.03356 & 31.90454 & 17.00661 \\
\hline
\end{tabular}

- Hasil perhitungan pada beban 1000 gr

Hasil Perhitungan pada beban 1000 gr

\begin{tabular}{|c|c|c|c|c|c|c|c|c|c|c|c|}
\hline NO & $\begin{array}{c}\text { Putaran } \\
\text { n (rpm) }\end{array}$ & $\begin{array}{c}\text { Daya } \\
\text { Ne (kw) }\end{array}$ & $\begin{array}{c}P_{\mathrm{e}} \\
(\mathrm{kpa})\end{array}$ & $\begin{array}{c}\mathrm{FC} \\
(\mathrm{kg} / \mathrm{jam}) \\
\end{array}$ & $\begin{array}{c}\mathrm{Qa} \\
\left(\mathrm{m}^{3} / \mathrm{s}\right)\end{array}$ & $\begin{array}{c}\text { SFC } \\
(\mathrm{kg} / \mathrm{kw} . j \mathrm{am})\end{array}$ & $\begin{array}{c}\mathrm{m}_{\mathrm{a}} \\
(\mathrm{kg} / \mathrm{jam})\end{array}$ & $\begin{array}{c}\begin{array}{c}\mathrm{m}_{\mathrm{at}} \\
(\mathrm{kg} / \mathrm{jam})\end{array} \\
\end{array}$ & AFR & $\begin{array}{c}\eta v \\
(\%)\end{array}$ & $\begin{array}{l}\text { nth } \\
(\%)\end{array}$ \\
\hline 1 & 1850 & 0.465388035 & 196.0216 & 0.18 & 0.000853 & 0.386774 & 3.532924 & 9.82905 & 19.62736 & 35.9437 & 21.05828 \\
\hline 2 & 1800 & 0.45280998 & 196.0216 & 0.162198 & 0.000814 & 0.358203 & 3.368511 & 9.82905 & 20.76792 & 34.27097 & 22.73795 \\
\hline 3 & 1750 & 0.440231925 & 185.4259 & 0.15871 & 0.0008 & 0.360514 & 3.311893 & 9.82905 & 20.86762 & 33.69495 & 22.59219 \\
\hline 4 & 1700 & 0.42765387 & 180.128 & 0.155368 & 0.000786 & 0.363304 & 3.254291 & 9.82905 & 20.94564 & 33.10891 & 22.41867 \\
\hline 5 & 1650 & 0.415075815 & 174.8301 & 0.151385 & 0.000772 & 0.364716 & 3.19565 & 9.82905 & 21.10948 & 32.5123 & 22.33191 \\
\hline
\end{tabular}


- Hasil perhitungan pada beban $1250 \mathrm{gr}$

Perhitungan pada beban 1250 gr

\begin{tabular}{|c|c|c|c|c|c|c|c|c|c|c|c|}
\hline NO & $\begin{array}{c}\text { Putaran } \\
\text { n (rpm) }\end{array}$ & $\begin{array}{c}\text { Daya Ne } \\
\text { (kw) }\end{array}$ & $\begin{array}{c}P_{\mathrm{e}} \\
\text { (kpa) }\end{array}$ & $\begin{array}{c}\mathrm{FC} \\
(\mathrm{kg} / \mathrm{jam})\end{array}$ & $\begin{array}{c}\mathbf{Q a} \\
\left(\mathrm{m}^{3} / \mathrm{s}\right)\end{array}$ & $\begin{array}{c}\mathrm{SFC} \\
(\mathrm{kg} / \mathrm{kw} . \mathrm{jam})\end{array}$ & $\begin{array}{c}\mathrm{m}_{\mathrm{a}} \\
(\mathrm{kg} / \mathrm{jam})\end{array}$ & $\begin{array}{c}\mathrm{m}_{\mathrm{at}} \\
(\mathrm{kg} / \mathrm{jam})\end{array}$ & AFR & $\begin{array}{c}\eta v \\
(\%)\end{array}$ & $\begin{array}{l}\eta \text { th } \\
(\%)\end{array}$ \\
\hline 1 & 1850 & 0.581735044 & 245.027 & 0.199459 & 0.000866 & 0.34287 & 3.586054 & 9.82905 & 17.97886 & 36.48424 & 23.75477 \\
\hline 2 & 1800 & 0.566012475 & 245.027 & 0.1968 & 0.000853 & 0.347696 & 3.532924 & 9.82905 & 17.95185 & 35.9437 & 23.42508 \\
\hline 3 & 1750 & 0.550289906 & 231.7823 & 0.186835 & 0.000827 & 0.339522 & 3.424193 & 9.82905 & 18.32732 & 34.83747 & 23.98902 \\
\hline 4 & 1700 & 0.534567338 & 225.16 & 0.182222 & 0.000814 & 0.340878 & 3.368511 & 9.82905 & 18.48573 & 34.27097 & 23.89358 \\
\hline 5 & 1650 & 0.518844769 & 218.5376 & 0.173647 & 0.000786 & 0.33468 & 3.254291 & 9.82905 & 18.74084 & 33.10891 & 24.33606 \\
\hline
\end{tabular}

\section{Hubungan Daya Mesin dengan Oksigen}

Dari nilai daya efektif ( $\mathrm{Ne}$ ) yang hasilnya dapat dilihat pada tabel perhitungan kemudian digambarkan pada gambar grafik 3.5. Dari gambar tersebut menjelaskan bahwa untuk semua pembebanan (750, 1000 dan 1250 gram) semakin tinggi daya Mesin semakin menurunkan prosentase Oksigen, hal ini disebabkan kapasitas oksigen yang terkandung didalam udara pada ruang bakar akan semakin berkurang karena, naiknya frekuensi pergerakan piston yang membutuhkan udara lebih banyak untuk pembakaran, sehingga semakin tinggi putaran akan menaikkan daya mesin yang membutuhkan semakin banyak udara yang terbakar, akibatnya kapasitas udara dalam ruang bakar semakin berkurang seiring dengan berkurangnya prosentase oksigen yang terkandung dalam udara

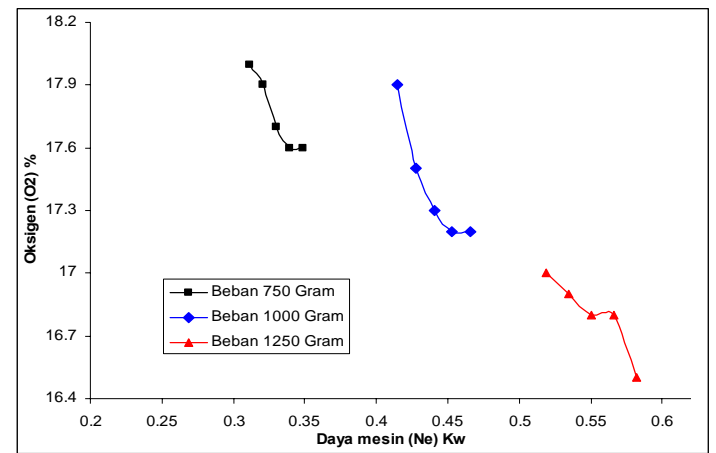

Grafik Hubungan antara oksigen dengan Daya mesin

\section{Hubungan Pemakaian Bahan Bakar dengan Oksigen}

Dari nilai pemakaian bahan bakar (FC) yang hasilnya dapat dilihat pada tabel perhitungan kemudian digambarkan pada gambar gambar 3.6. Dari gambar tersebut menjelaskan bahwa untuk pembebanan 750 dan 1000 gram, pemakaian bahan bakar antara 0,15 hingga $0,16 \mathrm{~kg} / \mathrm{jam}$ kebutuhan udara pada proses pembakaran cendrung menurun.Hal yang sama terjadi pada pembebanan 1250 gram,dengan pemakaian bahan bakar antara 0,17 hingga 0,18,5. Keadaan tersebut diatas disebut campuran miskin dan menyebabkan pembakaran tidak sempurna. Diatas 0,16 untuk beban 750 dan 1000 Udara dan bahan bakar relatif seimbang. Hal serupa juga terjadi pada beban 1250, pemakaian bahan bakar diatas 0,18,5 hingga 0,19.Keadaan ini disebut pembakaran sempurna. Pada beban 1250 gram pemakaian udara kembali menurun tajam, karena bahan bakar mendominasi ruang bakar dibanding dengan udara, maka terjadi lagi pembakaran tidak sempurna yang disebut campuran kaya.

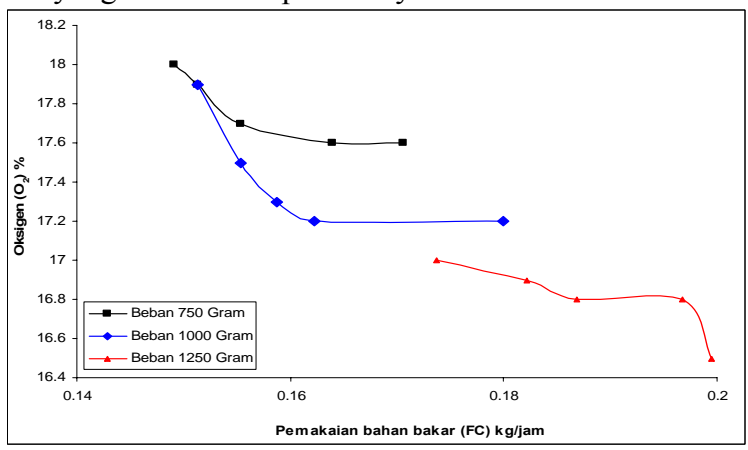

Grafik hubungan antara Pemakaian Bahan Bakar dengan Oksigen 


\section{Hubungan Effisiensi Thermal dengan Oksigen}

Dari nilai efesiensi thermal $\left(\eta_{\text {th }}\right)$ yang hasilnya dapat dilihat pada tabel perhitungan kemudian digambarkan pada gambar grafik 3.7. Menjelasakan bahwa; semakin tinggi beban semakin menurunkan prosentase oksigen, hal ini dikarenakan oleh kenaikan momen torsi akibat penambahan pembebanan sehingga, membutuhkan pemakaian udara yang lebih besar untuk proses pembakaran, mengakibatkan oksigen yang terkandung pada udara ikut berkurang.

Pada pembebanan750 dan 1250gram ,sebelum effisiensi maksimum prosentase oksigen naik seirng dengan naiknya effisiensi, tapi setelah Effisiensi maksimum malah sebaliknya yang terjadi, hal ini disebabkan sebelum effisiensi maksimum terjadi campuran miskin dan sesudah effisiensi maksimum terjadi campuran kaya.Pada beban 1000 gram,kenaikan effisiensi tidak dirtai dengan kenaikan Oksigen hingga effisiensi maksimum karena pada keadaan ini terjadi pembakaran sempurna.Ketika diatas effisiensi maksimum prosentase oksigen menurun disertai turunnya effisiensi, hal ini dikarenakan oleh campuran kaya.

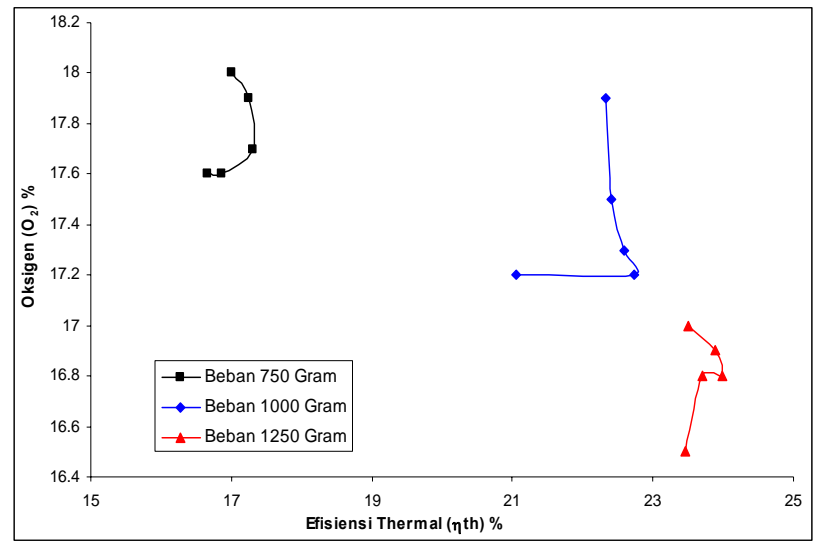

Grafik Hubungan antara Efisiensi thermal dengan Oksigen dengan

\section{Hubungan Daya Mesin dengan Carbondioksid}

Dari nilai daya efektif $(\mathrm{Ne})$ yang hasilnya dapat dilihat pada tabel perhitungan kemudian digambarkan pada gambar grafik 3.8. Dari gambar tersebut menjelaskan bahwa untuk pembebanan 750 dan 1000, 1250 gram prosentase Carbondioksid naik secara linier dengan kenikan daya mesin, hal ini disebabkan semakin besar daya mesin semakin membutuhkan pemakaian udara yang lebih besar pula,sehingga reaksi antara bahan bakar dengan Zat azam lebih meningkat dalam proses pembakaran kondisi ini adalah salah satu karakter Mesin Diesel yang beropersi pada tekanan udara lebih.

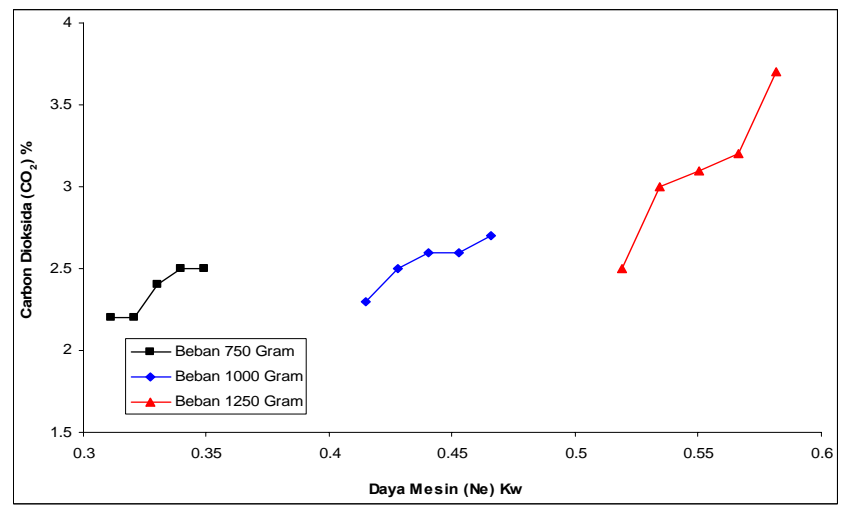

Grafik Hubungan antara Daya Mesin dengan Carbon dioksida

\section{Hubungan Pemakaian Bahan bakar dengan Carbondioksid}

Dari nilai pemakaian bahan bakar (FC) yang hasilnya dapat dilihat pada tabel perhitungan kemudian digambarkan pada gambar grafik 3.9. Menjelasakan bahwa; semakin Banyak pemakaian bahan bakar semakin banyak Carbondioksid yang terbentuk, hal ini sangat jelas pada pembebanan 1250 grm,dengan beban yang besar akan membutuhkan kapasitas bahan bakar dan udara yang besar pula untuk 
memperoleh enersi pada pembakaran didalam ruang bakar, itulah sebabnya semakin banyak pemakaian bahan bakar semakin banyak Carbon dan zat asam(Carbondioksid) yang terbentuk.

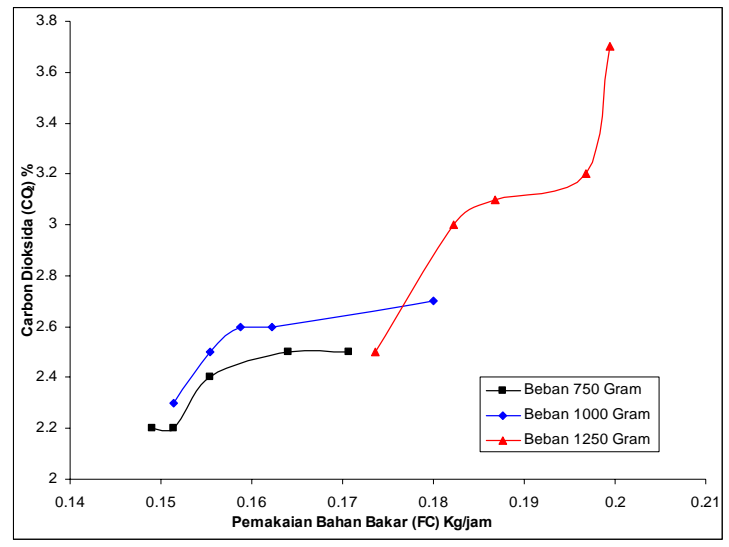

Grafik Hubungan antara Pemakaian bahan bakar dengan Carbon Dioksida

\section{Hubungan Efisiensi Thermal dengan Carbondioksid}

Dari nilai efesiensi thermal $\left(\eta_{\text {th }}\right)$ yang hasilnya dapat dilihat pada tabel perhitungan kemudian digambarkan pada gambar grafik 3.10 menjelasakan bahwa semakin tinggi beban semakin menaikkan prosentase Carbondioksid,tapi Tidak selamanya menaikkan efisiensi Thermal. Kenaikan dan penurunan Efisiensi Thermal diakibatkan oleh pembakaran yang tidak sempurna, tapi tidak mempengaruhi prosentase kenaikan Carbon dioksid. Hal ini disebabkan oleh laju aliran udara pada proses pembakaran semakin meningkat, mengakibatkan pembentukan Carbondioksid semakin meningkat pula.

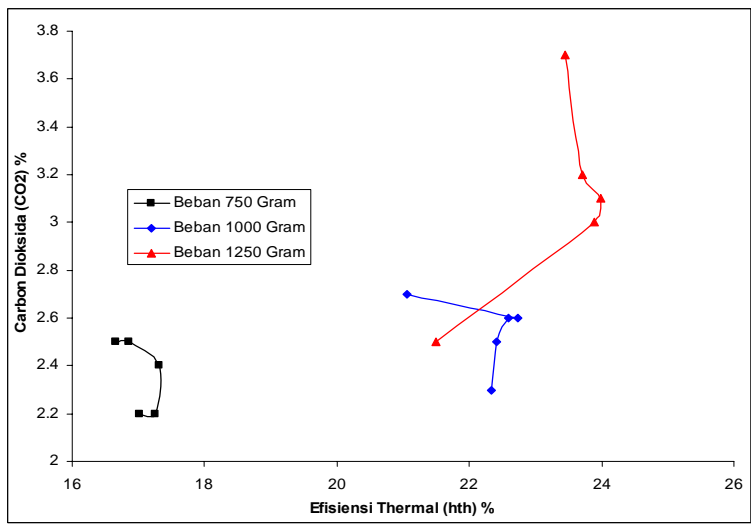

Grafik Hubungan antara Efisiensi thermal dengan Carbon Dioksida

\section{Hubungan Daya Mesin dengan Carbonmonoksid}

Dari nilai daya efektif ( $\mathrm{Ne}$ ) yang hasilnya dapat dilihat pada tabel perhitungan kemudian digambarkan pada gambar grafik 3.11. Dari gambar tersebut menjelaskan bahwa untuk pembebanan 750 dan 1000 gram kenaikan Daya Mesin belum ada Carbonmonoksid yang dihasilkan oleh gas hasil pembakaran, pada beban 1250 gram menampakkan kenaikan Daya Mesin menghasilkan Carbonmonoksid sebesar 0,1 \%.konstan pada setiap penambahan bahan bakar dan udara. Penyebabnya adalah; beban dibawah 1250 gram perbandingan udara dan bahan bakar pada proses pembakaran tidak signifikan yang berarti tidak memberikan pengaruh terhadap terbentuknya Carbonmonoksid, karena laju aliran udara masih seimbang dengan konsumsi pemakaian bahan bakar. Sangat berbeda dengan pembebanan 1250 gram,reaksi bahan bakar dengan udara pada proses pembakaran memberikan perbandingan sangat signifikan yang berarti perbandingan udara dan bahan bakar tidak seimbang lagi.Akibat ketidak seimbangan tersebut menyebabkan bahan bakar tidak semuanya ikut terbakar,inilah yng menyebabkan terbentuknya Carbonmonoksid yang sangat membahayakan kehidupan makhluk hidup. 


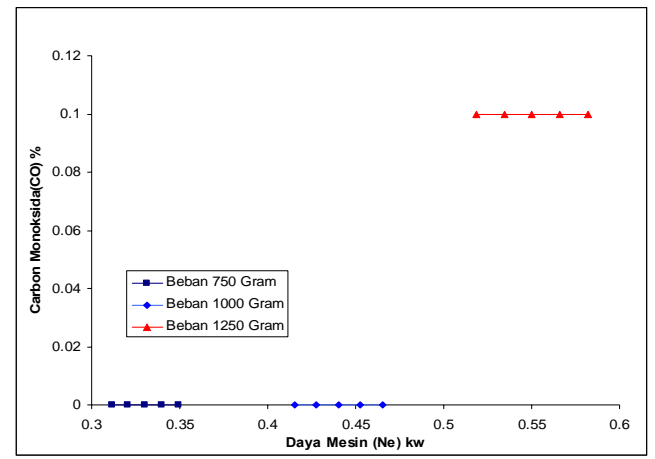

\section{Hubungan Pemakaian Bahan bakar dengan Carbonmonoksid}

Dari nilai pemakaian bahan bakar (FC) yang hasilnya dapat dilihat pada tabel perhitungan kemudian digambarkan pada gambar grafik 3.12. Dari gambar tersebut menjelaskan bahwa untuk semua beban, penambahan bahan bakar tidak mempengaruhi kenaikan prosentase Carbon monoksid. Untuk beban 750 dan 1000 gram karena pembakaran masih dalam keadaan seimbang,sehingga tidak terbentuk Carbon monoksid, Pada beban 1250 gram.kenaikan pemakaian bahan bakar juga tidak mempengaruhi kenaikan Carbonmonoksid,tetapi pada pembebanan ini telah terbentuk Carbon monoksid.Hal ini disebabkan oleh adanya domonasi Bahan bakar dalam ruang pembakaran sehingga sebahagian bahan bakar tidak terbakar menyebabkan terbentuknya carbonmonoksid pada gas buang.

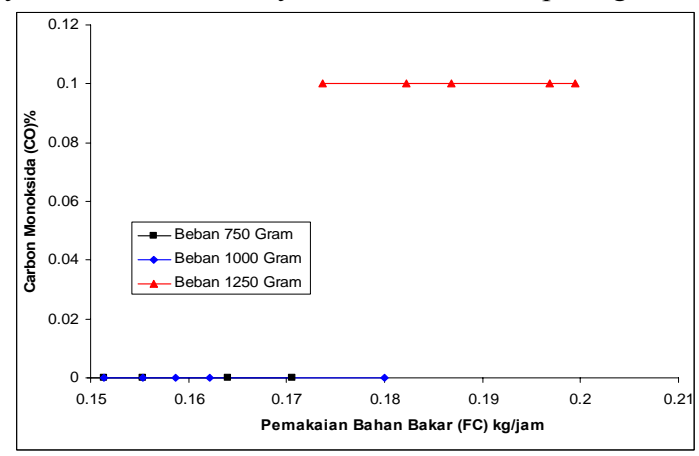

Grafik Hubungan antara Pemakaian bahan bakar dengan Carbon Monoksida

\section{Hubungan Efisiensi Thermal dengan Carbonmonoksida}

Dari nilai efesiensi thermal $\left(\eta_{\mathrm{th}}\right)$ yang hasilnya dapat dilihat pada tabel perhitungan kemudian digambarkan pada gambar grafik 3.13. Dari gambar tersebut diperlihatkan bahwa untuk semua beban, kenaikan efisiensi tidak mempengaruhi kenaikan prosentase Carbon monoksid. Untuk beban 750 dan 1000 gram perbandingan bahan bakar dan udara masih seimbang sehingga, terjadi pembakaran sempurna menyebabkan terbentuknya Carbon monoksid kecil kemungkinan, Pada beban 1250 gram,.kenaikan Efisiensi thermal juga tidak mempengaruhi kenaikan Carbonmonoksid, tetapi pada pembebanan ini telah terbentuk Carbon monoksid.Hal ini disebabkan oleh adanya domonasi Bahan bakar dalam ruang pembakaran sehingga terjadi campuran kaya menyebabkan sebahagian bahan bakar tidak ikut terbakar, maka terbentuklah carbonmonoksid dan terdeteksi pada gas buang.

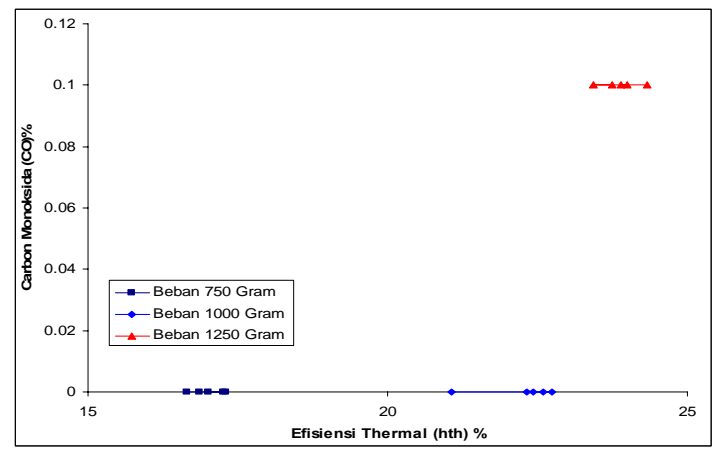

Grafik Hubungan Efisiensi Thermal dengan Carbonmonoksida 


\section{Hubungan Daya Mesin dengan Oksida Nitrogen}

Dari nilai daya efektif ( $\mathrm{Ne}$ ) yang hasilnya dapat dilihat pada tabel perhitungan kemudian digambarkan pada gambar grafik 3.14. Dari gambar tersebut menjelaskan bahwa untuk semua pembebanan (750, 1000 dan 1250 gram) semakin tinggi daya Mesin semakin menurunkan prosentase Oksida Nitrogen dan semakin tinggi pembebanan akan menaikkan kadar prosentase Oksida Nitrogen, hal ini disebabkan naiknya tekanan dan temperatur pada setiap perubahan pembebanan, daya Mesin bertambah karena momen Torsi mengalami kenaikan .Kemudian pada setiap beban, kenaikan daya mesin akan menurunkan prosentase Oksida Nitrogen, dikarenakan tekanan udara yang masuk ke ruang kompressi semakin menurun menyebabkan prosentase Oksida Nitrogen juga mengalami penurunan.

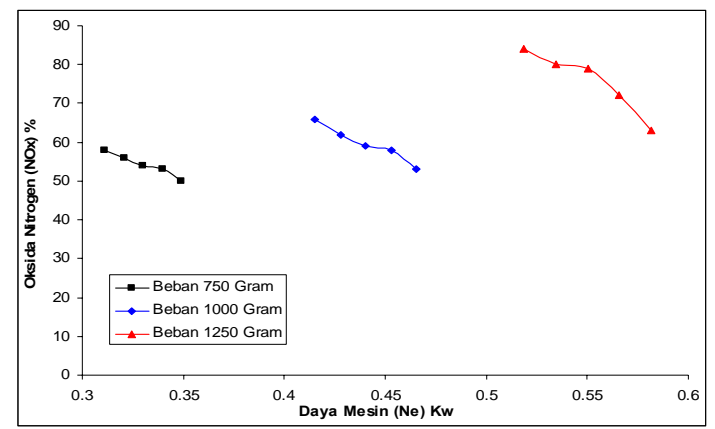

Grafik Hubungan Daya mesin dengan Oksida Nitrogen

Hubungan Pemakaian Bahan bakar dengan Oksida Nitrogen

Dari nilai pemakaian bahan bakar (FC) yang hasilnya dapat dilihat pada tabel perhitungan kemudian digambarkan pada gambar grafik 3.15. Dari gambar tersebut menjelaskan bahwa untuk semua beban, penambahan bahan bakar akan menurunkan prosentase Oksida Nitrogen. Hal ini dikarenakan kenaikan pemakaian bahan bakar pada proses pembakaran akan mengurangi jumlah kebutuhan udara sehingga kadar Oksida Nitrogen yang terkandung didalam udara ikut juga berkurang Pada setiapemakaian bahan bakar dan udara yang lebih besar pula sehingga menyebabkan prosentase Oksida Nitrogen.iku bertambah.

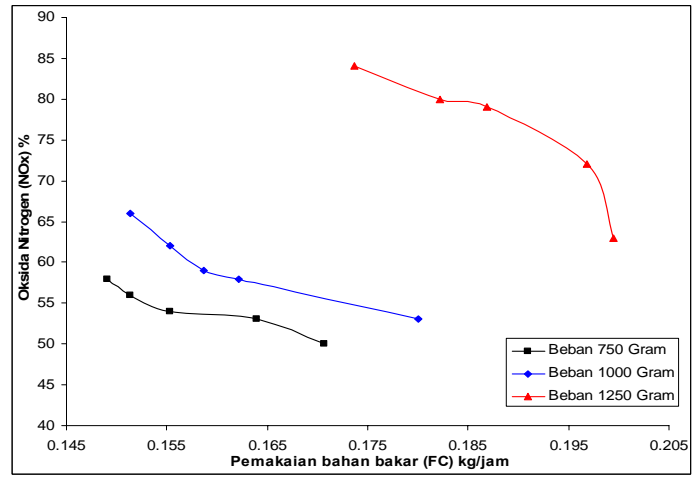

Grafik Hubungan antara Oksida Nitrogen dengan Pemakaian Bahan bakar

\section{Hubungan Efisiensi Thermal dengan Oksida Nitrogen}

Dari nilai efesiensi thermal $\left(\eta_{\text {th }}\right)$ yang hasilnya dapat dilihat pada tabel perhitungan kemudian digambarkan pada gambar grafik 3.16. Dari gambar tersebut menjelaskan bahwa kenaikan dan penurunan Efisiensi thermal akan tetap menaikkan unsur Oksida Nitrogen pada setiap pembebanan mesin, dan setiap kenaikan beban akan menaikkan unsur Oksida Nitrogen tapi tidak selamanya diikuti dengan pertambahan Efisiensi thermal.Hal ini disebabkan pada semua keadaan proses pembakaran baik dalam keadaan sempurna, maupun pembakaran tidak sempuna kandungan unsur Oksida Nitrogen tidak mengalami penurunan karena, bahkan semakin bertambah seiring naiknya kebutuhan bahan bakar pada proses pembakaran. 


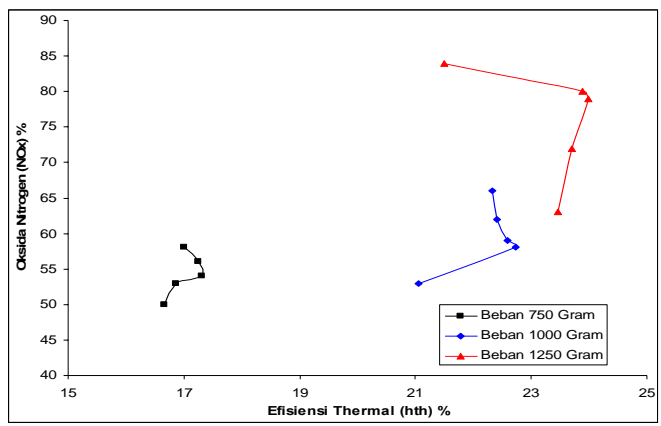

Grafik Hubungan Efisiensi Thermal dengan Oksida Nitrogen

Hubungan Daya Mesin, Pemakaian bahan bakar dan Efisiensi Thermal, terhadap Hidro Carbon

Dari nilai daya efektif ( $\mathrm{Ne})$, nilai pemakaian bahan bakar (FC), dan nilai efesiensi thermal $\left(\eta_{\text {th }}\right)$ yang hasilnya dapat dilihat pada tabel perhitungan kemudian digambarkan pada gambar grafik 3.17, 3.18 dan 3,19 dari gambar tersebut menjelaskan bahwa untuk parameter, Daya mesin,Pemakaian bahan bakar dan Efisiensi thermal hubungannya dengan Hidro Carbon hasil yang diperoleh pada parameter-parameter tersebut rata-rata dibawah angka 0 ( nol) yang berarti nihil.Hal ini dkarenakan Mesin beropersi didalam ruangan, dengan demikian unsur unsur penyebab terbentuknya Hidro Carbon, seperti asap yang tebal, debu, temperatur tinggi dan gas sisa pembakaran, kesemuanya ini jumlahnya relatif kecil.

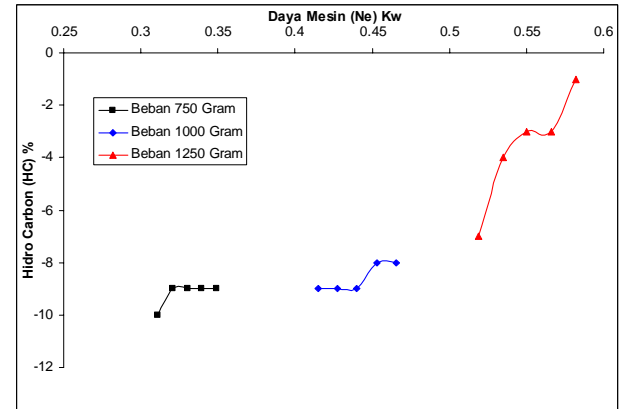

Grafik Hubungan antara Hidro Carbon dengan Daya mesin

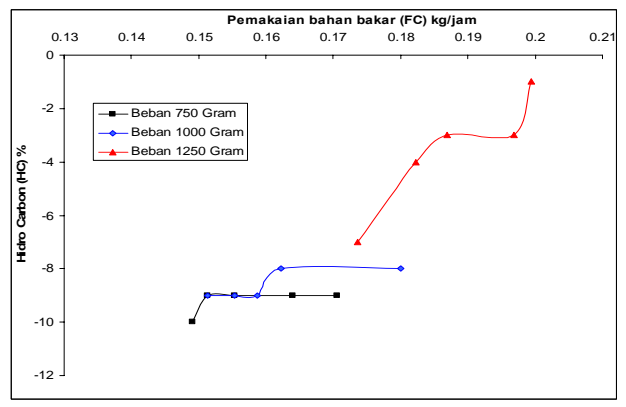

Grafik Hubungan antara Hidro Carbon dengan Pemakai Bahan Bakar

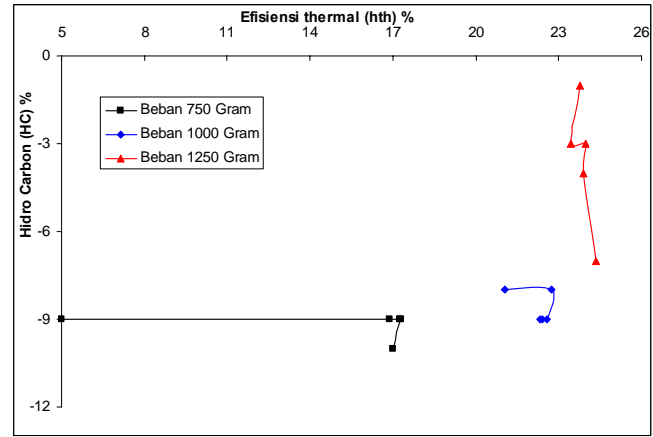

Grafik Hubungan antara Hidro Carbon dengan Efisiensi Thermal 
Dari penjelasan penjelasan diatas memberikan hasil, bahwa unsur-unsur yang membahayakan kehidupan makhluk hidup disekitar pengoperasian Mesin dalam keadaan aman, karena zat -zat yang dihasilkan oleh gas buang Mesin Diesel Yanmar L 40 masih dalam kondisi yang diizinkan yaitu Carbon Monoksida dibawah 0,3\%.

\section{KESIMPULAN}

Setelah dilakukan penelitian maka maka dapat disimpulkan bahwa :

1. Semakin besar pembebanan semakin menaikkan daya mesin, kadar oksigennya menurun .Daya mesin 0,349 - 0,518 (Kw), kadar oksigennya $18-16,5 \%$, kadar carbon dioksida mengalami kenaikan yaitu 2,5 - 3,7 \%, kadar oksida nitrogen berkurang dari $84 \%$ menjadi $50 \%$, dan menaikkan kadar carbon monoksid dari 0 hingga $0,1 \%$

Semakin besar pembebanan pemakaian bahan bakar semakin naik yaitu 0,149-0,199 kg/jam kadar oksigen menurun yaitu 18 - 16,5\%, kadar carbon dioksida naik dari 2,5 hingga 3,7 \%, kadar oksida nitrogen juga mengalami penurunan dari 84 hingga $50 \%$, kadar carbon monoksid naik dari 0 sampai $0,1 \%$. Perubahan Efisiensi thermal sangat mempengaruhi penurunan dan kenaikan unsur- unsur kimia yang terkandung didalam gas buang,Efisiensi Thermal 16,66 - 24,33\%, kadar oksigen turun dari 18 $16,5 \%$, carbon dioksida naik dari $2,5-3,7 \%$, kadar oksida nitrogen turun dari $84-50 \%$, dan menghasilkan carbon monoksid sebesar $0,1 \%$

2. Carbonmonksid yang dihasilkan oleh gas buang Mesin Diesel Yanmar L 40 sebesar 0,1\% lebih kecil dari $0,3 \%$ masih dalam kondisi yang diizinkan, layak untuk dioperasikan

\section{DAFTAR PUSTAKA}

Petrovesky. N, Marine Internal Combustion Engie, Translated from the Russion By Horace, E. Isakson Mir Publisher Moscow.

Streeter Victor L, Wylie Benjamin E, Prijono arko, Mekanika Fluida, Edisi Delapan Jilid 2, Penerbit Erlangga, Jakarta.

Trommelmans. J, Prinsip-Prinsip Mesin Diesel untuk Otomotif, Penerbit PT Rosda Jayaputra Jakarta

Wiranti Arismunandar, Motor Diesel Putaran Tinggi, Edisi IV, Penerbit ITB, Bandung, 1983

Wiranto Arismunandar, Penggerak Mula Motor Bakar Torak, Edisi III, Penerbit ITB, Bandung, 1980 